\title{
UPAYA REHABILITASI TANAH SAWAH TERDEGRADASI DENGAN MENGGUNAKAN KOMPOS SAMPAH KOTA DI DESA SERDANG KECAMATAN BERINGIN KABUPATEN DELI SERDANG
}

\author{
Effort Rehabilitation on Paddy Fields with Degradation by Composting Municipal Waste in \\ Serdang Village, Beringin Subdistrict, Deli Serdang Regency
}

Fitra Syawal", Abdul Rauf, Rahmawaty

Program Studi Pascasarjana Fakultas Pertanian USU, Medan 20155

*Corresponding author : fitrasyawalharahap@gmail.com

\begin{abstract}
Utilization of organic matter is one very big step in improving soil fertility, and will determine the productivity of the soil. The role of organic matter not only plays a role in the provision of plant nutrients, but which is much more important to the improvement of physical properties, soil chemical properties, soil biological properties. It is strongly related that through the application of organic materials can be attempted to stabilize the degraded soil, this research is aimed at Organizing organic materials to rehabilitate the physical, chemical, biological properties of soil in paddy fields in Serdang Village, Beringin Subdistrict, Deli Serdang Regency. This research was conducted in Serdang Village of Beringin Subdistrict, Deli Serdang Regency with Altitude \pm 11 Meter above Sea Level. This research used non factorial Randomized Block Design (RBD) with organic dosage treatment $(B)$ Compost Waste City, consisting of 5 (five) levels: $B_{0}$ : Control, $B_{1}$ : 1,5\% (38,70 ton / ha ), $B_{2}: 3 \%$ (77.40 ton / ha), B3: 4.5\% (116.10 ton / ha), B4: 6\% (154.8 ton / ha). Provision of organic fertilizer as much as 38.70 ton / ha to 77.40 ton / ha can improve soil properties and production of rice crops in Serdang Village Beringin District until the soil organic matter content reaches $3 \%$.
\end{abstract}

Key words: Organic Matter, Soil properties, Paddy Fields

\begin{abstract}
ABSTRAK
Pemanfaatan bahan organik merupakan salah satu langkah sangat besar dalam meningkatkan kesuburan tanah, dan akan menentukan produktivitas tanah. Peranan bahan organik tidak hanya berperan dalam penyediaan hara tanaman saja, namun yang jauh lebih penting terhadap perbaikan sifat fisik,sifat kimia tanah, sifat biologi tanah. Hal ini sangat terkait bahwa melalui aplikasi bahan organik dapat diupayakan merahabilitasi tanah sawah terdegradasi, Penelitian ini bertujuan untuk Pemberiaan bahan organik dapat merehabilitasi sifat fisika, kimia, biologi tanah pada tanah sawah di Desa Serdang, Kecamatan Beringin, Kabupaten Deli Serdang. Penelitian ini dilaksanakan di Desa Serdang Kecamatan Beringin, Kabupaten Deli Serdang dengan Ketinggian \pm 11 Meter diatas Permukaan Laut. Penelitian ini menggunakan Rancangan Acak Kelompok (RAK) non faktorial dengan perlakuan dosis bahan organik (B) Kompos Sampah Kota, yang terdiri dari 5 (lima) taraf yaitu : $\mathrm{B}_{0}:$ Kontrol, $\mathrm{B}_{1}: 1,5 \%$ (38,70 ton/ha), $\mathrm{B}_{2}: 3 \%$ (77,40 ton/ha), $\mathrm{B}_{3}: 4,5 \%$ (116,10 ton/ha), $\mathrm{B}_{4: 6} \%$ (154,8 ton/ha). Pemberian pupuk organik sebanyak 38,70 ton/ha sampai 77,40 ton/ha dapat memperbaiki sifat tanah dan produksi tanaman padi sawah di Desa Serdang Kecamatan Beringin hingga kandungan bahan organik tanah mencapai $3 \%$.
\end{abstract}

Kata Kunci: Bahan Organik, Sifat Tanah, Tanah Sawah

\section{PENDAHULUAN}

Pada Lahan sawah terdegradasi salah satunya terindikasi karena bahan organik dan kalium rendah.Bahan organik memiliki peran penting dalam menentukan kemampuan tanah 
untuk mendukung tanaman, sehingga jika kadar bahan organik tanah menurun, kemampuan tanah dalam mendukung produktivitas tanaman juga menurun peningkatan produksi pertanian baik kualitas maupun kuantitas, mengurangi pencemaran lingkungan, dan meningkatkan kualitas lahan secara berkelanjutan.

Peranan bahan organik sangat besar dalam meningkatkan kesuburan tanah, dan akan menentukan produktivitas tanah. Peranan bahan organik tidak hanya berperan dalam penyediaan hara tanaman saja, namun yang jauh lebih penting terhadap perbaikan sifat fisik, biologi dan sifat kimia tanah lainnya seperti terhadap $\mathrm{pH}$ tanah, kapasiatas pertukaran kation dan anion tanah, daya sangga tanah dan netralisasi unsur meracun seperti $\mathrm{Fe}, \mathrm{Al}, \mathrm{Mn}$ dan logam berat lainnya (Atmojo, 2003).

Selain kompos jerami padi ada juga kompos sampah kota. Menurut Sandrawati et al., (2007) kompos sampah kota dapat dibuat dari sampah kota berupa sampah pasar dan sampah rumah tangga yang telah mengalami pelapukan (pengomposan) diharapkan dengan penggunaan pupuk kompos yang tepat yaitu kompos sampah kota maka Sifat fisik tanah dapat diperbaiki yaitu struktur dantekstur tanah melalui pembentukan agregat yang lebih stabil, gembur serta aerasi dan drainase tanah yang baik.

\section{BAHAN DAN METODE}

Penelitian ini dilaksanakan di Desa Serdang Kecamatan Beringin, Kabupaten Deli Serdang dengan Ketinggian \pm 11 Meter diatas Permukaan Laut .Analisa tanah dilaksanakan di Laboratorium Fisika dan Konservasi Tanah dan Air dan Laboratorium Riset Teknologi Fakultas Pertanian Universitas Sumatera

\section{HASIL DAN PEMBAHASAN}

\section{Pengaruh Pemberian bahan organik pemberian bahan organik kompos sampah kota terhadap sifat fisika tanah}

Pengaruh pemberian bahan organik kompos sampah kota pada pertanaman padi
(Suwarnoet al, 2009 dalam Guntur et al, 2015). Menurut Badan Litbang Pertanian (2006) bahan organik sangat bermanfaat bagi

Utara. Penelitian ini dilaksanakan pada bulan Maret 2017 sampai Juli 2017. Bahan dalam penelitian ini adalah Tanah sawah di Desa Serdang, Pupuk Organik (kompos sampah kota), pupuk Urea, SP36 dan $\mathrm{KCl}$ sebagai pupuk dasar, insektisida, fungisida dan bahan yang dibutuhkan lainnya. Alat-alat yang digunakan dalam penelitian ini adalah cangkul, handtractor, Bor Tanah gembor, tugal, tali rafia, meteran, gunting, pisau, pacak sampel, papan nama, handsprayer, kamera, alat tulis dan alat yang dibutuhkan lainnya.

Penelitian ini menggunakan Rancangan Acak Kelompok (RAK) non faktorial dengan perlakuan dosis bahan organik (B) Kompos Sampah Kota, yang terdiri dari 5 (lima) taraf yaitu : $\mathrm{B}_{0}=$ Kontrol, $\mathrm{B}_{1}=1,5 \%(38,70$ ton/ha), $\mathrm{B}_{2}=3 \%$ (77,40 ton $\left./ \mathrm{ha}\right), \mathrm{B}_{3}=4,5 \%$ (116,10 ton/ha), $\mathrm{B}_{4}=6 \%$ (154,8 ton/ha). Dari hasil penelitian dianalisis dengan menggunakan sidik ragam berdasarkan model linier sebagai berikut:

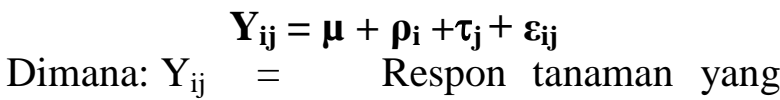
diamati, $\mu=$ Nilai tengah umum, $\rho_{\mathrm{i}}=$ Efek dari blok ke-i, $\tau_{\mathrm{j}}=$ Efek perlakuan pada ulangan ke-j, $\varepsilon_{\mathrm{ij}}=$ Efek eror dari perlakuan ke-j dan blok ke-i. Jika dari hasil analisis sidik ragam menunjukkan pengaruh yang nyata, maka dilanjutkan dengan uji beda rataan menggunakan uji DMRT pada taraf 5 $\%$ (Sastrosupadi, 2000). Adapun Parameter yang diukur sifat fisika : Bulk Density $\left(\mathrm{g} / \mathrm{cm}^{3}\right)$, Porositas (\%). sifat Kimia,; pH Tanah, C- Oragnik $\mathrm{N}$ - Total (\%), C/N, P-Tersedia (ppm), $\mathrm{K}_{2} \mathrm{O}$ (mg/100), KTK (Me/100), KB (\%), sifat biologi : Bahan Organik (\%), Total Mikroba (CFU)

sawah terhadap sifat fisika tanah dapat dilihat dari parameter pengamatan yang meliputi sifat fisika tanah Bulk density $\left(\mathrm{gr} / \mathrm{cm}^{3}\right)$, Porositas (\%) tanah. Hasil analisis sidik ragam terhadap data sifat fisika menunjukkan bahwa pemberian bahan organik kompos sampah kota berpengaruh nyata terhadap sifat fisika tanah. 
Hasil uji beda rataan pada Tabel 1 terhadap sifat fisika tanah Bulk density $\left(\mathrm{gr} / \mathrm{cm}^{3}\right)$, Porositas (\%), menggunakan uji jarak berganda Duncan, disajikan pada Tabel 1. Bulk Density yang tertinggi terdapat pada Tabel 1. Sifat fisika tanah Bulk density $\left(\mathrm{gr} / \mathrm{cm}^{3}\right)$, Porositas $(\%)$, akibat pemberian bahan organik kompos sampah kota

\begin{tabular}{ccc}
\hline \multirow{2}{*}{ Perlakuan } & \multicolumn{2}{c}{ Sifat Fisika Tanah } \\
\cline { 1 - 2 } & $\mathrm{BD}(\mathrm{gr} / \mathrm{cm} 3)$ & Prositas $(\%)$ \\
$\mathrm{B}_{0}$ & $1.14 \mathrm{a}$ & $56.56 \mathrm{~d}$ \\
$\mathrm{~B}_{1}$ & $1.08 \mathrm{~b}$ & $59.1 \mathrm{c}$ \\
$\mathrm{B}_{2}$ & $1.06 \mathrm{~b}$ & $59.82 \mathrm{bc}$ \\
$\mathrm{B}_{3}$ & $1.05 \mathrm{bc}$ & $60.51 \mathrm{ab}$ \\
$\mathrm{B}_{4}$ & $1.03 \mathrm{bc}$ & $61.64 \mathrm{a}$ \\
\hline Keterangan & Angka yang diikuti oleh huruf yang sama pada kolum yang sama menunjukkan
\end{tabular}

perlakuan $\mathrm{B}_{3}(4,5 \%)$. Hal ini disebabkan Tanah lapisan permukaan atas yang kaya bahan organik dan gembur mempunyai bulk density lebih rendah dari lapisan bawah yang pejal dengan kandungan humus rendah. Menurut Buckman dan Brady (1982) tanah permukaan berbutir-butir, hal ini disebabkan oleh kandungan bahan organik yang relative tinggi. Butiran menyebabkan kerapatan lindak tanah yang rendah dan total pori yang tinggi. Porositas yang tertinggi terdapat pada perlakuan $\mathrm{B}_{4}(6 \%)$ sedangkan terendah pada peralakuan $\mathrm{B}_{0}$ (Kontrol). Pengaruh pemberian bahan organik kompos sampah kota terhadap Porositas yang terbaik $\mathrm{B}_{4}(6 \%)$ tidak berbeda

\section{Pengaruh Pemberian bahan organik pemberian bahan organik kompos sampah kota terhadap sifat Kimia tanah}

Pengaruh pemberian bahan organik pemberian bahan organik kompos sampah kota pada pertanaman padi sawah terhadap sifat kimia tanah dapat dilihat dari parameter yang meliputi $\mathrm{pH}$ Tanah, C-organik, N-Total, C/N, P-Tersedia, Serta KTK tanah. Hasil analisis sidik ragam terhadap data sifat kimia tersebut menunjukkan bahwa pemberian bahan organik kompos sampah berpengaruh nyata terhadap sifat kimia tanah.

Hasil uji beda rataan pada Tabel 2 terhadap sifat kimia tanah dapat dilihat dari perlakuan $\mathrm{B}_{0}$ (Kontrol) sedangkan terendah pada peralakuan $\mathrm{B}_{4} \quad(6 \%)$. Pengaruh pemberian bahan organik kompos sampah kota terhadap Bulk Density yang terbaik $B_{4}$ $(6 \%)$ namum tidak berbeda nyata dengan 
Pengaruh pemberian bahan organik dapat meningkatkan $\mathrm{pH}$ tanah meskipun peningkatannya masih dalam kategori masam. Tingkat kemasaman tanah akibat dari pemberian bahan organik bergantung pada tingkat kematangan dari bahan organik yang diberikan, batas kadaluarsa dari bahan organik dan jenis tanahnya.

Tabel 2. Sifat kimia tanah pH Tanah, C-organik, N-Total, C/N, P-Tersedia, Serta KTK Tanah akibat pemberian bahan organik kompos sampah kota

\section{Sifat Kimia Tanah}

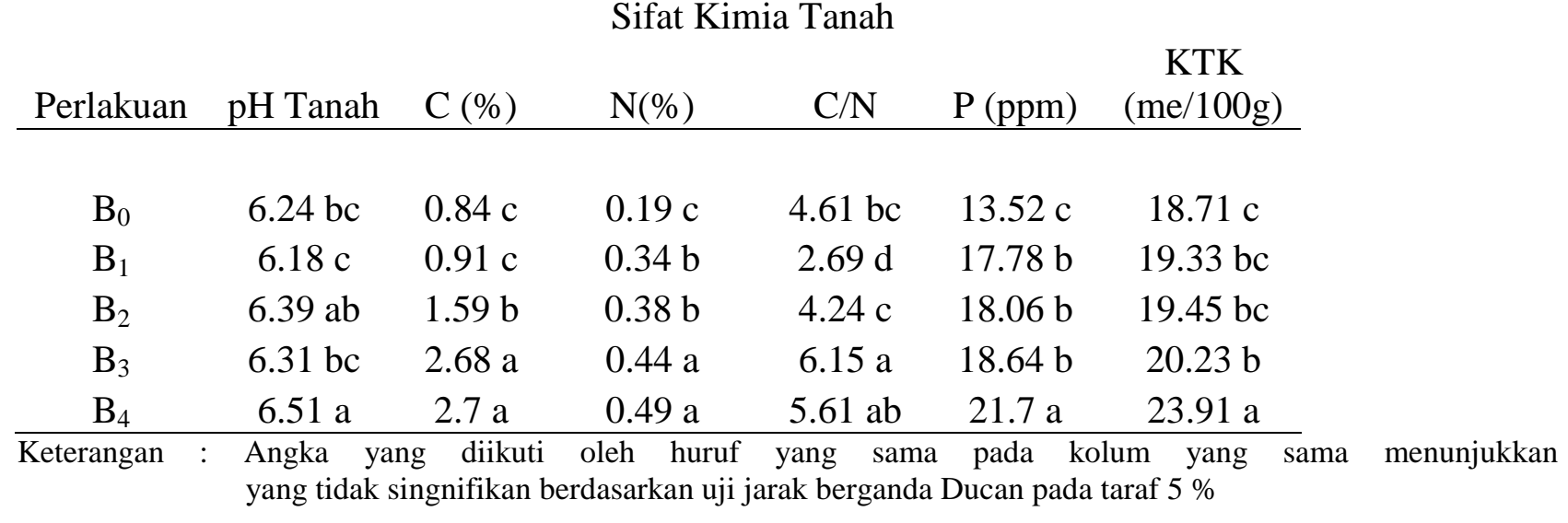

Menurut Suntoro (2003). Jika penambahan bahan organik yang masih belum matang akan penyebabkan lambatnya proses peningkatan belum terdekomposisi dengan baik dan masih melepaskan asam-asam organik.

C-Organik yang tertinggi terdapat pada perlakuan $\mathrm{B}_{4}(6 \%)$ sedangkan terendah pada peralakuan $\mathrm{B}_{0}$ (Kontrol). Pengaruh pemberian bahan organik kompos sampah kotaterhadap C-Organik yang terbaik adalah perlakuan $\mathrm{B}_{4}(6 \%)$ namum tidak berbeda nyata dengan $\mathrm{B}_{3}(4,5 \%)$. peningkatan $\mathrm{C}$ organik pada tanah yang diberi kompos dan. Semakin banyak pupuk organik yang ditambahkan ke dalam tanah, semakin besar pula peningkatan kandungan C- organik dalam tanah Menurut Utami dan Handayani (2003) menjelaskan bahwa dengan pemberian bahan organik dapat meningkatkan kandungan C-organik tanah dan juga dengan peningkatan C-organik tanah juga dapat mempengaruhi sifat tanah menjadi lebih baik secara fisik, kimia dan biologi.

$\mathrm{N}$ - Total yang tertinggi terdapat pada perlakuan $\mathrm{B}_{4}(6 \%)$ sedangkan terendah pada peralakuan $\mathrm{B}_{0}$ (Kontrol). Pengaruh pemberian bahan organik kompos sampah kotaterhadap $\mathrm{N}$-Total yang terbaik adalah perlakuan $\mathrm{B}_{4}(6$ $\%)$ namum tidak berbeda nyata dengan $\mathrm{B}_{3}$ $(4,5 \%)$. Peningkatan N-total tanah ini berasal dari mineralisasi bahan organik yang diberikan. Hardjowigeno (2003) menjelaskan bahwa proses hilangnya $\mathrm{N}$ yang ada di dalam tanah dapat disebabkan karna diserap oleh tanaman, digunakan oleh mikroorganisme, $\mathrm{N}$ masih dalam bentuk $\mathrm{NH}_{4}{ }^{+}$yang diikat oleh mineral liat illit sehingga tidak dapat digunakan oleh tanaman, $\mathrm{N}$ juga masih dalam bentuk $\mathrm{NO}_{3}{ }^{-}$yang mudah tercuci oleh adanya air hujan, dan kondisi lahan yang masih tergenang dengan drainase buru serta fertilasi udara kurang baik juga dapat terjadi proses denitrifikasi dan juga volatilisasi dalam bentuk $\mathrm{NH}_{3}$ (amonia).

$\mathrm{C} / \mathrm{N}$ Tanah yang tertinggi terdapat pada perlakuan $\mathrm{B}_{3}(4,5 \%)$ sedangkan terendah pada peralakuan $\mathrm{B}_{1}(1,5 \%)$. Pengaruh pemberian bahan organik kompos sampah kotaterhadap $\mathrm{C} / \mathrm{N}$ yang terbaik adalah perlakuan $\mathrm{B}_{3}(4,5 \%)$ namum tidak berbeda nyata dengan $\mathrm{B}_{4}(6 \%)$. Pemberian bahan organik yang telah cukup matang pada saat tanam atau seminggu setelah tanam dapat memberikan kondisi yang tepat tersebut. Menurut Rachma Sutanto (2002) menyatakan Rasio C/N yang tinggi akan menyebabkan sulitnya terjadinya dekomposisi, sedangkan Rasio $\mathrm{C} / \mathrm{N}$ yang renda menjukkan persentase yang lebih besar daripada bahan yang mudah terdekomposisi. 
P-Tersedia yang tertinggi terdapat pada perlakuan $\mathrm{B}_{4}(6 \%)$ sedangkan terendah pada peralakuan $\mathrm{B}_{0}$ (Kontrol). Pengaruh pemberian bahan organik kompos sampah kotaterhadap P-Tersedia yang terbaik adalah perlakuan $\mathrm{B}_{4}(6 \%)$. Hal ini disebabkan asamasam organik yang dihasilkan dari proses bahwa bahan organik selain memperbaiki kesuburan fisik juga dapat meningkatkan $\mathrm{P}$ tersedia tanah karena dapat membentuk ikatan kompleks dengan $\mathrm{Al}$ terlarut sehingga mengurangi retensi $\mathrm{P}$ oleh $\mathrm{Al}$ dan $\mathrm{Fe}$.

KTK Tanah yang tertinggi terdapat pada perlakuan $\mathrm{B}_{4}(6 \%)$ sedangkan terendah pada peralakuan $\mathrm{B}_{0}$ (Kontrol). Pengaruh pemberian bahan organik kompos sampah kota terhadap KTK Tanah yang terbaik adalah perlakuan $\mathrm{B}_{4}(6 \%)$. Pemberian Bahan organik sekalipun kecil, namun besar pengaruhnya terhadap KTK tanah, sehingga makin tinggi bahan organik tanah makin tinggi pula KTK tanah. Menurut Sanchez

\section{Pengaruh Pemberian bahan organik pemberian bahan organik kompos sampah kota terhadap sifat Biologi tanah}

Pengaruh pemberian bahan organik pemberian bahan organik kompos sampah kotapada pertanaman padi sawah terhadap sifat Biologi tanah meliputi Bahan Organik dan Total Mikroba. Hasil analisis sidik ragam terhadap data sifat Biologi tersebut menunjukkan bahwa pemberian Bahan Organik kompos sampah berpengaruh nyata terhadap sifat Biologi tanah. Hasil uji beda rataan pada Tabel 3 terhadap sifat Biologi tanah Bahan Organik dan Total Mikroba menggunakan uji jarak berganda Duncan, disajikan pada Tabel 3.

Bahan Organik Tanah yang tertinggi terdapat pada perlakuan $\mathrm{B}_{4}(6 \%)$ sedangkan terendah pada peralakuan $\mathrm{B}_{0}$ (Kontrol). Pengaruh pemberian bahan organik kompos sampah kotaterhadap Bahan Organik yang dekomposisi bahan organik dapat mengkhelat $\mathrm{Fe}$ dan $\mathrm{Al}$, sehingga $\mathrm{P}$ akan tersedia bagi tanaman, masam-masam organik dalam membentuk khelat dengan $\mathrm{Al}$ dan $\mathrm{Fe}$ yang mengakibatkan pelepasan fosfat dalam larutan tanah. Menurut Sanchez (1992) menyatakan

(1992) menyatakan bahwa bahan organik tanah secara tidak langsung berperan dalam meningkatkan kesetabilan agregat, kapasitas menahan air, KTK, daya sangga tanah serta menurunkan jerapan $\mathrm{P}$ oleh tanah. Semakin tinggi bahan organik di dalam tanah maka semakin tinggi KTK nya, dimana ketentuan ini berlaku jika faktor-faktor lain sama. Selanjutnya dikatakan bahwa besarnya KTK tanah dipengaruhi sifat dan ciri tanah yang antara lain adalah reaksi tanah atau $\mathrm{pH}$ dimana dengan meningkatnya $\mathrm{pH}$ tanah maka KTK pun akan meningkat (Hakim et al., 1986); Duxbury, Smith dan Doran, 1989).

terbaik adalah perlakuan $\mathrm{B}_{4}(6 \%)$ namum tidak berbeda nyata dengan $\mathrm{B}_{3}(4,5 \%)$. Total Mikroba Tanah yang tertinggi terdapat pada perlakuan $\mathrm{B}_{4}(6 \%)$ sedangkan terendah pada peralakuan $\mathrm{B}_{0}$ (Kontrol).

Pengaruh pemberian bahan organik kompos sampah kotaterhadap Total Mikroba yang terbaik adalah perlakuan $\mathrm{B}_{4}(6 \%)$ namum tidak berbeda nyata dengan $\mathrm{B}_{1}(1,5 \%)$ dan $\mathrm{B}_{3}(4,5 \%)$. Peningkatan mikrobia ini terjadi karena peranannya sebagai perombak yang pada akhirnya akan meningkatkan unsur-unsur hara penting bagi tanaman di dalam ini disebabkan Peningkatan kandungan C-organik dapat pula disebabkan oleh jumlah mikroorganisme yang mendekomposisi bahan organik tersebut relatif banyak.. Menurut Buckman and Brady (1982) populasi mikroorganisme tanah meningkat dengan adanya penambahan bahan organik ke dalam tanah ditinjau dari peredaran $\mathrm{CO}_{2}$. 
Tabel 3 . Sifat Biologi Tanah Bahan Organik dan Total Mikroba Tanah akibat pemberian bahan organik kompos sampah kota

\begin{tabular}{ccc}
\hline Perlakuan & \multicolumn{2}{c}{ Sifat Biologi Tanah } \\
& Bahan Organik $(\%)$ & Total Mikroba $(\mathrm{CF} /$ \\
\hline $\mathrm{B}_{0}$ & $1.45 \mathrm{c}$ & $4.9 \times 10^{7} \mathrm{c}$ \\
$\mathrm{B}_{1}$ & $1.57 \mathrm{c}$ & $6.4 \times 10^{7} \mathrm{ab}$ \\
$\mathrm{B}_{2}$ & $2.73 \mathrm{~b}$ & $6 \times 10^{7} \mathrm{~b}$ \\
$\mathrm{~B}_{3}$ & $4.62 \mathrm{a}$ & $6.5 \times 10^{7} \mathrm{ab}$ \\
$\mathrm{B}_{4}$ & $4.65 \mathrm{a}$ & $7.2 \times 10^{7} \mathrm{a}$ \\
\hline
\end{tabular}

Keterangan : Angka yang diikuti oleh huruf yang sama pada kolum yang sama menunjukkan yang tidak singnifikan berdasarkan uji jarak berganda Ducan pada taraf $5 \%$

\section{SIMPULAN DAN SARAN}

\section{Simpulan}

Pemberian pupuk organik sebanyak 38,70 ton/ha sampai 77,40 ton/ha dapat memperbaiki sifat tanah dan produksi tanaman padi sawah di Desa Serdang Kecamatan Beringin.

\section{Saran}

Untuk meningkatkan Produktivitas tanah sawah di Kecamatan Beringin disarakan pupuk organik sebanyak 38,70 ton/ha sampai 77,40 ton/ha hingga kandungan bahan organik tanah mencapai $3 \%$.

\section{DAFTAR PUSTAKA}

Atmojo, S. W. 2003. Peranan Bahan Organik Terhadap Kesuburan Tanah Dan Upaya Pengelolaannya. Pidato Pengukuhan Guru Besar Ilmu Kesuburan Tanah. Sebelas Maret University Press. Surakarta.

[Balittan]. 2005. Pupuk organik tingkatkan produksi pertanian. Warta Penelitiandan Pengembangan Pertanian Vol. 27 (6): 13-15.

[Badan Litbang] Badan Penelitian dan Pengembangan Pertanian. 2006. PupukOrganik dan Pupuk Hayati.Departemen Pertanian. Jakarta.

BPS 2015. Luas wilayah Kabupaten Deli serdang. www.deliserdangkab.bps.go.id. Diakses tanggal 26 Februari 2017

Guntur, P. O., Hardy, G., dan Razali. 2015. Pemetaan Status C-Organik Tanah Sawah Di Desa Sei Bamban, Kecamatan Sei Bamban Kabupaten Serdang Bedagai. Jurnal Agroekoteknologi Vol. 4 (1) :1830 1837.

Kurnia, U., Sudirman, dan Kusnadi, H. 2005. Rehabilitasi dan Reklamasi Lahan Terdegradasi. hlm 141-168 dalam Buku Teknologi Pengelolaan Lahan Kering. Pusat dan Pengembangan Tanah dan Agroklimat, Bogor.

Kyuma, K. 2004. Paddy Soil Science. Kyoto University Press and Trans Pacific Press. 280 p.

Nuraini. 2009. Pembuatan Kompos Jerami Menggunakan Mikroba Perombak Bahan Organik. Buletin Teknik Pertanian Vol. 14 (1): 23-26

Oktalaseva, W. Hermansah., dan Nurwanita, E. P. 2013. Karakteristik Kesuburan Tanah dan Potensial Haradari Bahan Organik Sisa Panen Padi Sawah Pada Beberapa Lokasi di Sumatera Barat. Fakultas Pertanian Universitas Andalas, Padang

Sandrawati, A, E.T. Sofyan, O. Mulyani. 2007. Pengaruh Kompos Sampah Kota dan Pupuk Kandang Sapi Terhadap Sifat Kimia Tanah dan Hasil Tanaman Jagung Manis (Zea mays saccharata) pada Fluventic Eutrudepts Asal 
Jatinagor Kabupaten Sumedang. Laporan Penelitian Dasar (LITSAR). Universitas Padjadjaran.

Sastrosupadi, A., 2000. Rancangan Percobaan Praktis Bidang Pertanian. Penerbit Kanisus. Yogyakarta.
Simarmata T, Joy B (2010) Pemulihan kesehatan dan peningkatan produksi padi pada lahan suboptimal dengan teknologi intensifikasi padi aerob terkendali berbasis organik (IPATIBO). Makalah. Fakultas Pertanian Universitas Padjajaran. Bandung. 